
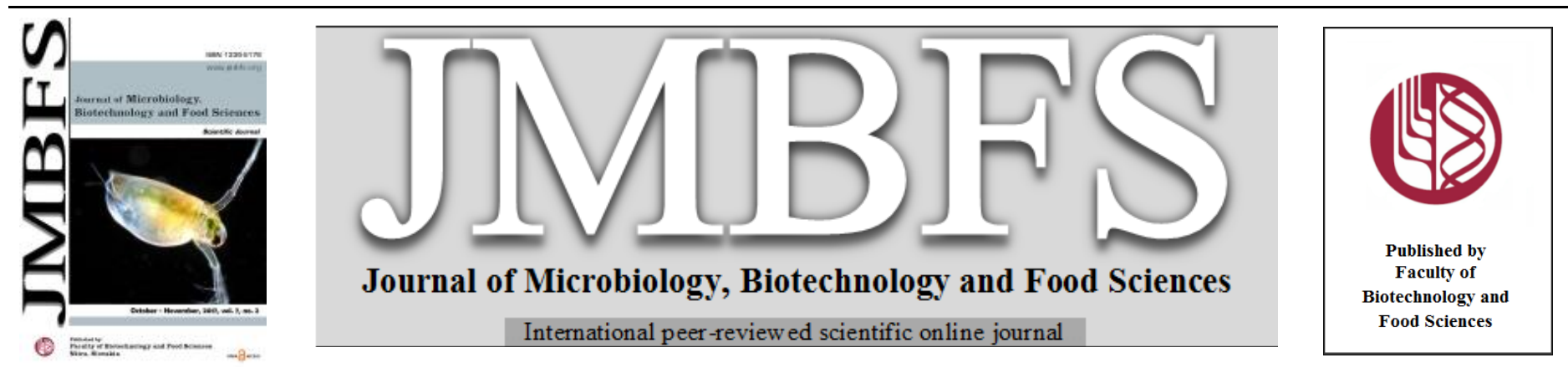

\title{
STRAIN IMPROVEMENT THROUGH MUTAGENESIS AND OPTIMIZATION OF PROTEASE PRODUCTION BY ASPERGILLUS TERREUS CJS-127 USING JATROPHA SEED CAKE AS SUBSTRATE
}

\section{Jyothna Bommasamudram and Somashekar Devappa*}

Address(es): Dr. Somashekar Devappa,

Senior Scientist, Microbiology and Fermentation Technology Department, CSIR-Central Food Technological Research Institute, Mysore-570020, Karnataka, India.

*Corresponding author: somshek@hotmail.com, somashekar@cftri.res.in

doi: 10.15414/jmbfs.2017.7.2.174-180

ARTICLE INFO

Received 8. 9. 2016

Revised 5. 9. 2017

Accepted 20. 9. 2017

Published 24. 9. 2017

Regular article

open 2 ACCESS

\begin{abstract}
Jatropha curcas seedcake (JSC), a byproduct of the biodiesel industry was utilized for the production of protease. To enhance the protease production, the parent strain of Aspergillus terreus CJS-127 subjected to UV (15, 30, 60, 90, 120 and $150 \mathrm{~min})$ and chemical mutagenesis by using ethyl methanesulphonate (EMS-125, 250 and $500 \mathrm{mg}$ ). Two mutant strains designated as UV-6 and EMS-5 selected for optimization of protease production using JSC medium by submerged fermentation. Under the optimized conditions of $\mathrm{pH}$ 7.0, temperature $30^{\circ} \mathrm{C}$, incubation period $72 \mathrm{~h}$, inoculum $10^{5} / \mathrm{ml}$ spores, $150 \mathrm{rpm}$ agitation, JSC at $2 \%$ level, the maximum protease production was 172.32 and $163.57 \mathrm{U} / \mathrm{ml}$ for EMS-5 and UV-6 mutant strains respectively. The addition of maltose (2\%) was found to enhance the protease production in the mutant strains. The protease activity increased by 2.30 and 2.41 folds for UV 6 and EMS 5 mutant strains after optimization of cultural conditions.
\end{abstract}

Keywords: Strain improvement, Jatropha seedcake, Protease, Aspergillus terreus CJS-127, mutagenesis

\section{INTRODUCTION}

Microorganisms play a vital role in technology for the production of intracellular and extracellular enzymes on an industrial scale (Gupta et al., 2002). Proteases constitute one of the most important groups of enzymes, and their annual sales account for $60 \%$ of the total world enzyme market (Turk, 2006). In recent years, there is renewed interest in the study of proteolytic enzymes, mainly due to the recognition that these enzymes not only play an important role in the cellular metabolic process but also have gained considerable attention in their commercial application. Proteases are industrially important due to their wide applications in leather processing, detergent industry, food industries, pharmaceutical, textile industry, etc. (Jellouli et al., 2009; Deng et al., 2010).

Jatropha curcas is a plant of economic importance owing to its nonedible oil being used as biofuel. Jatropha seed cake (JSC) is a waste by-product generated during biodiesel production. The JSC is very rich in protein; however, the presence of antinutrients and toxins limits its application in animal feeds. Hence, there is a need to utilize this seed cake, as a large quantity of it is generated while processing for biodiesel (Sharath $\boldsymbol{e t}$ al., 2014). Conversion of wastes into useful biomass by microorganisms and their enzymes is a new trend, and new proteaseproducing microorganisms and suitable fermentation technology are needed to meet the ever-growing demand for this enzyme (Rathakrishnan et al., 2012). Aspergillus terreus is a saprotrophic fungus prevalent in tropical and subtropical regions. The fungus has dominated the biological production of the "blockbuster" drugs known as statins. The statins are a class of drugs that inhibit HMG-CoA reductase and lead to lower cholesterol production. (Subhan et al., 2016). The statins are the largest selling class of drugs throughout the world. Sales for statins in 2005 were $\$ 25$ billion (Endo, 2010). A. terreus found as the potential strain for production of tannery protease in submerged fermentation (Chellapandi, 2010). In this study, A.terreus CJS-127 a locally isolated strain has been selected to generate mutants for enhanced production of protease. This particular fungus was selected as it was able to grow on JSC and produce protease. Strain improvement is an essential part of process development for fermentation products. Improved strains can be achieved by inducing genetic variation in the natural strain and subsequent screening. The mutagenesis and selection after random screening are still cost effective procedure, and reliable short-term strain development is frequently the method of choice (Rowlands, 2002; Iftikar et al., 2010). The enzyme production could be further enhanced by optimization of physiological and biological conditions.

The aim of this study was to isolate protease overproducing strains of A.terreus CJS-127 by mutagenesis using physical mutagens like UV radiation and a chemical mutagen -EMS (Ethyl methanesulphonate). The present study was also focused on the optimization of cultural conditions for higher yields of extracellular protease using JSC as substrate by submerged fermentation.

\section{MATERIALS AND METHODS}

\section{Culture and growth condition}

The microorganism used in the present study was A. terreus CJS-127, and the culture was isolated at CFTRI, Mysore and the culture was deposited at MTCC, India. The culture was grown on Czapek Dox agar (CDA) medium for 7 days at $25^{\circ} \mathrm{C}$ (Himedia, India). The subculture of the organism was done once in 15 days.

\section{Mutagenesis}

\section{UV mutagenesis}

For UV radiation mutagenesis, spores $\left(10^{5}\right.$ spores $\left./ \mathrm{ml}\right)$ of A. terreus CJS-127 parent strain were prepared using saline solution. $4 \mathrm{ml}$ of this suspension was taken in a sterile $9 \mathrm{~cm}$ Petri plate and kept in a sterile UV chamber with lids open and exposed to $254 \mathrm{~nm}$ UV radiations. The exposure was carried out at a distance of $20 \mathrm{~cm}$. Petri plates were exposed to UV light for 15, 30, 60, 90, 120 and 150 min. After taking out from UV chamber, Petri plate lids were closed; wrapped with black paper and kept in dark for $12 \mathrm{~h}$. Next day, the treated spore suspension was serially diluted, $100 \mu 1$ of each dilution was spread on CDA plates and incubated for 7 days. The surviving colonies were counted. After 7 days of incubation, six colonies were picked up based on colony morphology variation and designated as UV 1, UV 2, UV 3, UV 4, UV 5 and UV 6 and subcultured. These morphological variants were used for screening protease production.

\section{Chemical mutagenesis using Ethyl methanesulphonate (EMS)}

One $\mathrm{ml}$ of $10^{5}$ spores $/ \mathrm{ml}$ of spore suspension was treated with different concentration $(125,250$ and $500 \mathrm{mg}$ ) of chemical mutagen EMS (SRL, India) for a period of 30 and $60 \mathrm{~min}$ respectively. The treated spore suspension was kept on a shaker incubator at $150 \mathrm{rpm}$. In another set of experiment $1 \mathrm{ml}$ spore, suspension with a constant concentration of EMS $(125 \mathrm{mg})$ was incubated for time periods of 15, 45 and $90 \mathrm{~min}$. After treatment, the spore suspension was washed thrice with sterile distilled water, resuspended in saline and stored in dark for $12 \mathrm{~h}$. Next day, the mutation induced spore suspension was serially diluted 
and plated on CDA plates. After EMS treatment, the plates were incubated at $30^{\circ} \mathrm{C}$ for 5 or 7 days until the colonies appeared. The surviving colonies were counted. Then any colonies showing morphology different from that of the parent strain were picked out, followed by inoculation and cultivation as a single colony on a CDA plate. The resulting strains were subjected to protease assay. Untreated spores were also plated as the control. The per cent survival rate of colonies was calculated as follows:

Survival rate $=($ Number of test colonies/ No. of control colonies $)$ X 100

\section{Submerged Fermentation}

The Jatropha curcas seeds were procured from local market, and the Jatropha seed cake was prepared after the extraction of oil. The dried and ground JSC powder was taken at $2 \%$ level in a150 ml Erlenmeyer flask with $25 \mathrm{ml}$ of distilled water and sterilized for $30 \mathrm{~min}$ at $121^{\circ} \mathrm{C}$. Spores suspension was prepared using $0.85 \%$ saline with $0.1 \%$ of Tween 20 and JSC medium was inoculated with $1 \mathrm{~m}$ of the spore suspension of $10^{5} / \mathrm{ml}$. The flasks were kept on rotary shaker at $25^{\circ} \mathrm{C}$ at $150 \mathrm{rpm}$. The time course of protease production was checked by growing the culture for a period of 7 days.

The selection criteria for mutants were based on morphological deviation of the colony structure from that of the wild type culture. A small portion of the colony variant was taken out in a loop and subcultured on to the slants. This subcultured mutant slants were used for checking the protease production.

\section{Enzyme Assay}

Protease enzyme was assayed in the reaction mixture containing $3.0 \mathrm{ml}$ of $0.6 \%$ freshly prepared Casein Hammarsten (SRL chemicals, India) in $0.05 \mathrm{M}$ sodium phosphate buffer $\mathrm{pH} 7.50$. The reaction mixture was incubated for $20 \mathrm{~min}$ a $37^{\circ} \mathrm{C}$. The reaction was terminated by adding $3 \mathrm{ml}$ of $110 \mathrm{mM}$ trichloroacetic acid. The precipitate was filtered using Whatman No.1 filter paper and $2 \mathrm{ml}$ of filtrate was collected in fresh tubes. $5 \mathrm{ml}$ of $500 \mathrm{mM}$ sodium carbonate and $1 \mathrm{ml}$ of Folin-Ciocalteau reagent (1:1 diluted) were added and incubated at room temperature for $30 \mathrm{~min}$. The filtrate was collected using Whatman no.1 paper, and tyrosine liberated during casein hydrolysis was estimated by using Lowry's method (1951). One unit of protease activity was defined as the amount of enzyme required to liberate $1 \mu \mathrm{mol}$ tyrosine/ml per min.

Optimization studies for protease production

\section{Effect of inoculum concentration}

The cultures used for optimization studies were UV 6 and EMS 5 mutant strains To optimize the inoculum level, spore suspension containing $10^{4}, 10^{5}, 10^{6}, 10$ and $10^{8} / \mathrm{ml}$ were prepared in sterile saline individually and inoculated into conical flasks having $25 \mathrm{ml} \mathrm{JSC} \mathrm{(2 \% )} \mathrm{medium.}$

\section{Effect of incubation temperature}

Flasks with protease production medium (2\% JSC) were inoculated with $10^{5}$ spores $/ \mathrm{ml}$ and incubated at various temperatures such as $25^{\circ} \mathrm{C}, 30^{\circ} \mathrm{C}$ and $35^{\circ} \mathrm{C}$ up to $144 \mathrm{~h}$ and the enzyme activity was determined.

\section{Effect of incubation period}

The effect of incubation period was carried out by incubating the culture for different periods of time in JSC medium $(2 \%)$. The culture media were kept at $30^{\circ} \mathrm{C}$ for $24,48,72,96,120$ and $144 \mathrm{~h}$ at $150 \mathrm{rpm}$. The protease activity was checked at the above period.

\section{Effect of pH}

$150 \mathrm{ml}$ conical flasks with $25 \mathrm{ml}$ of $2 \%$ JSC was adjusted to different $\mathrm{pH}$ using sodium citrate buffer for $\mathrm{pH} 5.0$ and sodium phosphate buffer for $\mathrm{pH}$ 6.0, 7.0 and 8.0. The enzyme assay was carried out.

\section{Effect of Jatropha seed cake concentration}

The effect of JSC concentration was carried out using 1\%, 2\%, 2.5\%, 3\%, 3.5\% and $4 \%$ in the medium and the protease was checked after $72 \mathrm{~h}$.

\section{Effect of agitation}

Effect of agitation on protease production was carried at 100, 150 and $200 \mathrm{rpm}$ on a rotary shaker and the protease was estimated at $72 \mathrm{~h}$

\section{Effect of different carbon and nitrogen sources on protease production}

The influence of other carbon sources in JSC medium was investigated using glucose, maltose and soluble starch (2\%). Similarly, the effect of nitrogen sources on protease production was studied using peptone, sodium nitrate and ammonium sulphate at $2 \%$ level along with JSC medium.

\section{RESULTS AND DISCUSSION}

\section{Isolation of UV mutants for enhanced protease production}

The parent strain of A. terreus CJS-127 was subjected to UV irradiation for different periods of time. UV treatment affected the morphology of the mutan colonies (Figure 1). The wild type strain A. terreus is brownish and gets darker as it ages on culture media. On Czapekdox agar media wild type colonies grow rapidly and have smooth, rigid margin colonies. The UV-6 mutant colonies were tiny minute colonies and cream colored colonies when compared to the wild type strains. The EMS-5 mutant colonies were more yellowish compared to wild type culture on Czapekdox media. The EMS-5 mutant colonies were floccose with hair like soft tufts. The plates having less than $1.00 \%$ of survival over the control (without UV treatment) showing colony morphological variation were selected for the screening of hyper-protease production. The per cent survival of UV treated cultures was in the range of $0.1-6 \%$. The data on survival of culture on UV treatment in response to exposure time is presented in Table 1. The results obtained in the present study indicated the highest spore-killing rate of $0.005 \%$ when the spores were exposed to UV for $90 \mathrm{~min}$. The minimum killing rate of $5.8 \%$ was observed when exposed for $15 \mathrm{~min}$, and with an increase in the exposure time, the killing rate increased. There was no growth of colonies, when the spores were treated with UV for 120 and $150 \mathrm{~min}$. There was a reduction in survival per cent of colonies with increased exposure to UV. Similar trend has been reported by other investigators (Leng \& Yan 2011; Yadav et al., 2011) The Six putative UV mutants were selected based on the morphological variation of colonies. The morphological variations observed were wrinkled, striated, filamentous, irregular, rhizoid, undulate, filiform, lobate and curled. The six UV mutants were grown on JSC medium, and they were screened for protease production.

The protease production by parent strain of A.terreus CJS-127 was maximum on the $6^{\text {th }}$ day, i.e., $71.33 \pm 0.72 \mathrm{U} / \mathrm{ml}$. The protease production by different mutan strains and parent strain is given in Figure 2. The protease production was maximum in UV 6 strain on $5^{\text {th }}$ day, i.e., $92.64 \pm 0.72$

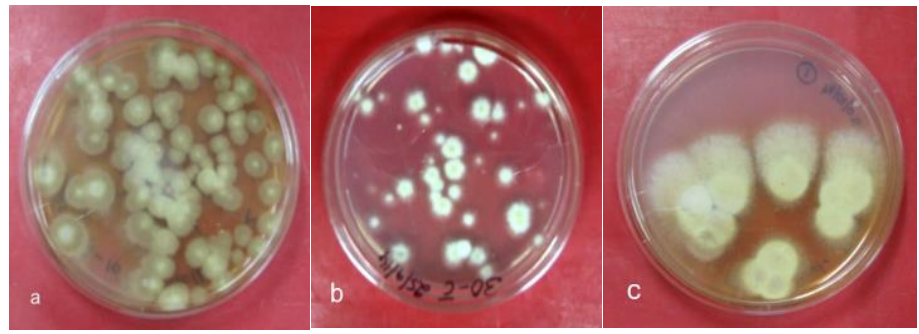

Figure 1 Morphology of a). Aspergillus terreus CJS-127 (wild type), b). UV-6 mutant colonies, c). EMS-5 mutant colonies

Table 1 Per cent survival of $A$. terreus after UV induced mutagenesis

\begin{tabular}{llll}
\hline Mutant strains & Treatments & No. of colonies & Survival (\%) \\
\hline CJS-127 & Control & $1.7 \times 10^{4}$ & 100 \\
UV 1 & UV-15 min & $1 \times 10^{3}$ & 5.80 \\
UV 2, UV 3 & UV-30 min & 46 & 0.27 \\
UV 4, UV 5 & UV-60 min & 24 & 0.24 \\
UV 6 & UV-90 min & 1 & 0.005 \\
UV 7 & UV-120 min & 0 & 0 \\
UV 8 & UV-150 min & 0 & 0 \\
\hline
\end{tabular}

$\mathrm{U} / \mathrm{ml}$ when the culture was grown at $25^{\circ} \mathrm{C}$. The protease production was $29.8 \%$ higher than the wild strain which produced maximum protease on the $6^{\text {th }}$ day under the same conditions (Figure 2). The least protease activity was observed in UV 5 with $26.4 \pm 0.43 \mathrm{U} / \mathrm{ml}$. A mutant strain of A. niger with lipase productivity of 2-fold higher was obtained after UV mutation (Ellaiah $\boldsymbol{e t}$ al., 2002a). Earlier reports have shown that 2 fold increase in acid protease production by UV mutant strain of A. niger in solid state fermentation (Radha et al., 2012). 


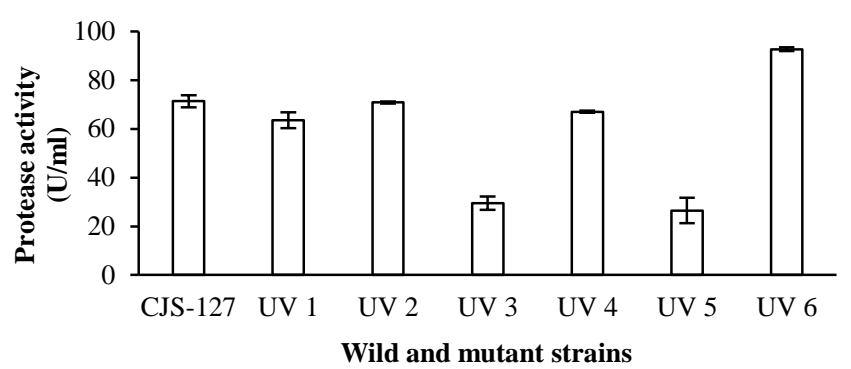

Figure 2 Protease production by UV mutant strains.

\section{Isolation of EMS mutants for enhanced protease production}

The strain improvement was carried out using different concentrations of chemical mutagen EMS. Morphological changes of colonies were observed with spore suspension exposed to EMS (Figure 1). The plates having less than $1.00 \%$ of survival rate over the control (without chemical treatment) were selected for the screening of hyper-protease producing mutants. The per cent survival of the culture is given in Table 2. The results showed a highest spore killing rate of $99 \%$ when $500 \mathrm{mg}$ of EMS was used and the lowest killing rate of $12 \%$ when treated with $125 \mathrm{mg}$ of EMS. The killing percentage increased with the increase in the concentration of EMS and exposure time of spores (Table 2). Thus, from the results, it was observed that the killing percentage of the spores was proportional to the concentration of both EMS and exposure period. The per cent survival of EMS treated cultures was in the range of $0.5-18 \%$. The survival of colonies was least in the case of spores treated with $500 \mathrm{mg}$ of EMS for $60 \mathrm{~min}$.

Table 2 Per cent survival of A. terreus after chemical mutagenesis (EMS)

\begin{tabular}{lccc}
\hline Mutant No. & Treatments & $\begin{array}{c}\text { No. of } \\
\text { colonies }\end{array}$ & $\begin{array}{c}\text { Survival } \\
(\%)\end{array}$ \\
\hline CJS-127 & ---- & $1.7 \times 10^{4}$ & 100 \\
EMS 7 & $100 \mu 1-15 \mathrm{~min}$ & $3 \times 10^{3}$ & 17.64 \\
EMS 1, EMS 8 & $100 \mu 1-30 \mathrm{~min}$ & $1.9 \times 10^{3}$ & 11.17 \\
EMS 9 & $100 \mu 1-45 \mathrm{~min}$ & $1.2 \times 10^{3}$ & 7.05 \\
EMS 2, EMS 10 & $100 \mu 1-60 \mathrm{~min}$ & $1.09 \times 10^{3}$ & 6.41 \\
EMS 11 & $100 \mu 1-90 \mathrm{~min}$ & $7.6 \times 10^{2}$ & 4.47 \\
EMS 3 & $200 \mu 1-30 \mathrm{~min}$ & $1 \times 10^{3}$ & 5.80 \\
EMS 4 & $200 \mu 1-60 \mathrm{~min}$ & $7.4 \times 10^{2}$ & 4.35 \\
EMS 5 & $400 \mu 1-30 \mathrm{~min}$ & $3 \times 10^{2}$ & 1.76 \\
EMS 6 & $400 \mu 1-60 \mathrm{~min}$ & $1 \times 10^{2}$ & 0.58 \\
\hline
\end{tabular}

A total of eleven morphological variants were selected and screened for protease production using JSC in submerged fermentation. The colony morphological variations observed were circular, wrinkled, striated, filamentous, irregular, undulate, filiform, lobate, curled and floccose with hair like soft tufts. The colonies were distinctly different from that of the parent culture, and the colonies were streaked on to the slants for making spore suspension and then used for checking protease production. Initially, the mutant strains were screened for maximum protease production and the strain which produced maximum protease was selected for further optimization for enhanced protease production.

The protease production by the EMS mutant strains is given in Figure 3. Among several strains screened for protease, EMS 5 produced maximum protease on the $5^{\text {th }}$ day with $86.77 \pm 3.64 \mathrm{U} / \mathrm{ml}$. Figure $1 \mathrm{C}$ represents the mutant strain of EMS-5. EMS 7 strain produced the least protease with $52.3 \pm 0.72 \mathrm{U} / \mathrm{ml}$. The EMS-5 mutant strain produced protease $21.6 \%$ higher than the wild strain. But the activity was less when compared to the mutant strain obtained after UV mutagenesis. Radha et al., (2012) have reported similar results after mutagenesis. Mutation frequency was mentioned to be high when the survival rates were between 10 and $0.1 \%$ (Hopwood et al., 1985).

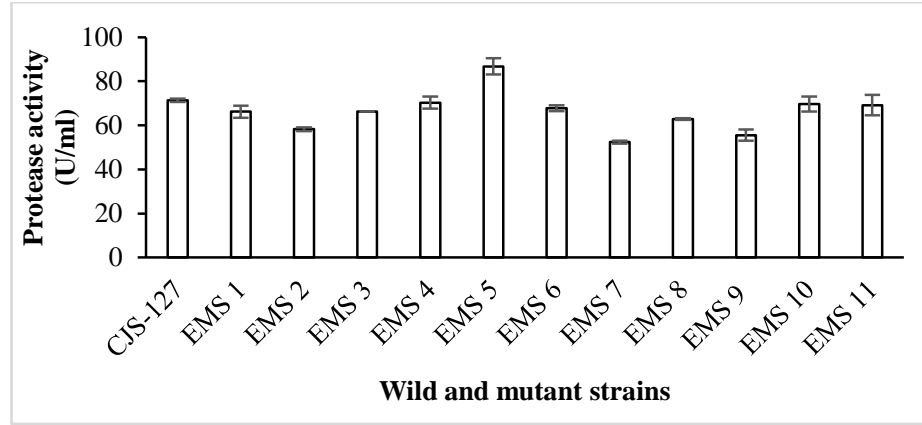

Figure 3 Protease production by EMS mutant strains

\section{Optimization Studies}

The yield of protease production was influenced by various physical and chemical parameters. To enhance the production of protease, mutant strains UV 6 and EMS 5 were selected for optimizing the cultural conditions.

\section{Effect of temperature}

The incubation temperature has a significant influence on the production of the enzyme in any microorganism. The submerged fermentation was carried out at 25,30 , and $35^{\circ} \mathrm{C}$. The optimum temperature for protease enzyme production was found to be $30^{\circ} \mathrm{C}$ and the enzyme activity for UV 6 and EMS 5 was $97.89 \pm 3.34$ $\mathrm{U} / \mathrm{ml}$ and $95.42 \pm 1.31 \mathrm{U} / \mathrm{ml}$ respectively. When the cultures were incubated at $25^{\circ} \mathrm{C}$ the maximum protease activity of both UV 6 and EMS 5 was $92.64 \pm 0.72$ $\mathrm{U} / \mathrm{ml}$ and $86.77 \pm 3.64 \mathrm{U} / \mathrm{ml}$ respectively. At $35^{\circ} \mathrm{C}$, there was a decrease in protease production among the mutant cultures were observed (Figure 4). As the temperature increased beyond $30^{\circ} \mathrm{C}$, the enzyme production was decreased Higher temperature may adversely affect the metabolic activity and enzyme production. The enzyme gets denatured at high temperature and loses its catalytic properties due to stretching and breaking of weak hydrogen bonds within enzyme structure (Conn et al., 1987). Raj et al., (2012) have found that $37^{\circ} \mathrm{C}$ was the optimum temperature for the production of protease by Pseudomonas aeruginosa by submerged fermentation. The incubation at temperatures other than $37^{\circ} \mathrm{C}$ was found to decrease the production of protease. Most of the fungi showed an optimum temperature for protease production between $28^{\circ} \mathrm{C}$ and $30^{\circ} \mathrm{C}$ (Chutmanop et al., 2008)
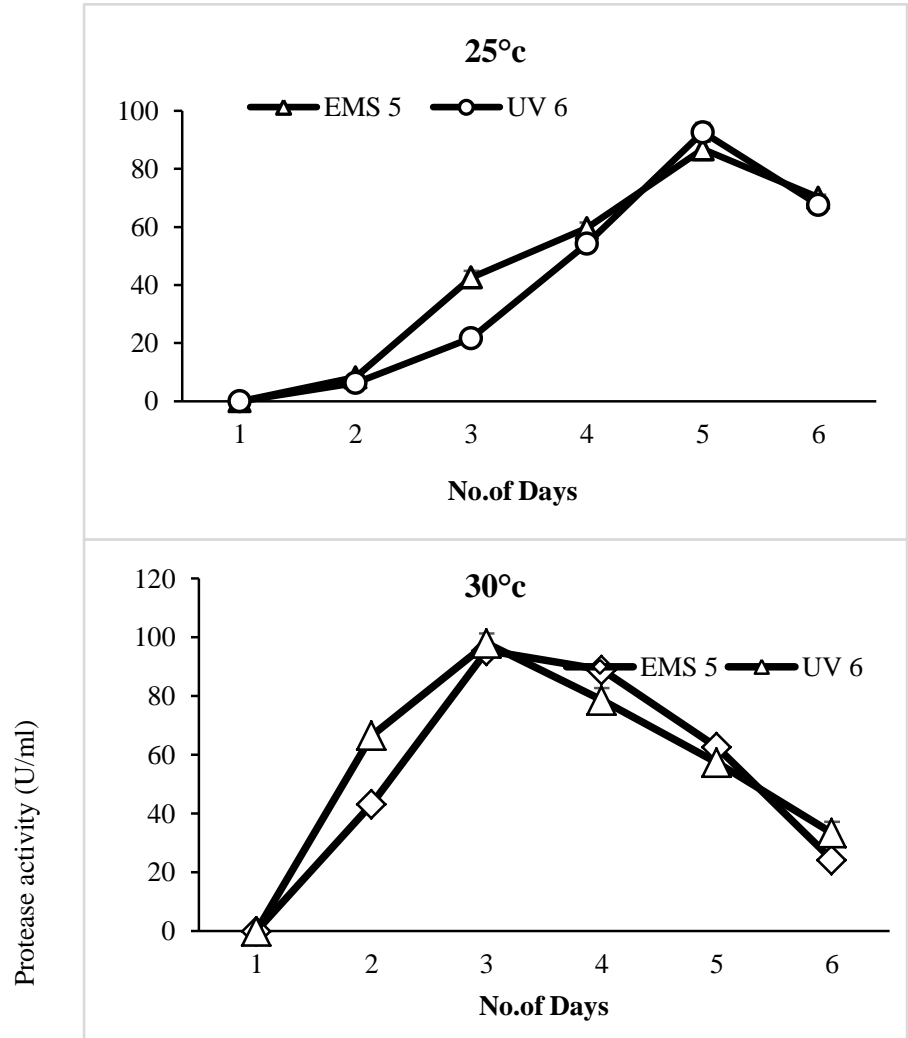

$35^{\circ} \mathrm{c}$

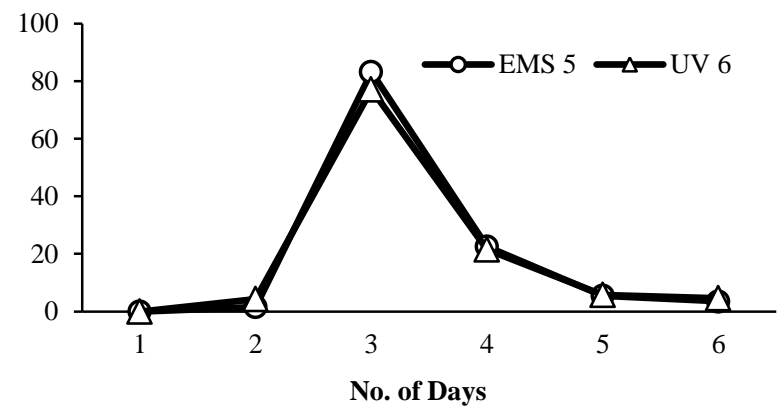

Figure 4 Effect of temperature on protease production 


\section{Effect of incubation period}

The enzyme production varies with the incubation time, as it is dependent on the growth of the organism. The mutant cultures were incubated for $24-120 \mathrm{~h}$ at $30^{\circ} \mathrm{C}$ and screened for protease production. Figure 5 illustrates the effect of incubation period on protease production. The maximum enzyme production was observed at $72 \mathrm{~h}$ for UV 6 and EMS 5 strains. The maximum protease activity for UV 6 and EMS 5 was $97.89 \pm 3.34$ and $95.42 \pm 1.31 \mathrm{U} / \mathrm{ml}$ respectively. The maximum amount of enzyme production was reported to be at $48 \mathrm{~h}$ for $P$. aeruginosa (Raj et al., 2012). The maximum protease of $95 \mathrm{U} / \mathrm{ml}$ was reported by Kranthi et al., (2012) using ground nut oil seed cake at $72 \mathrm{~h}$ by Rhizopus stolonifer under solid state fermentation. It is essential to detect the optimum incubation time at which an organism exhibits highest enzyme activity since organisms show considerable variation at different incubation periods (Kumar et al., 2012).

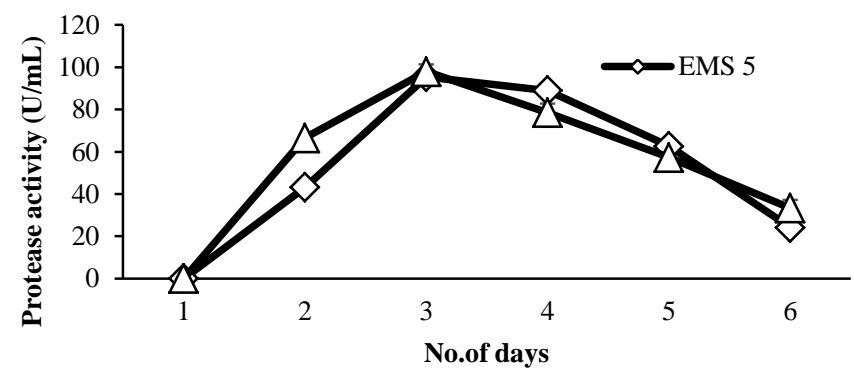

Figure 5 Effect of incubation period on protease production by mutant strains

\section{Effect of pH}

The effect of $\mathrm{pH}$ on protease production using JSC as a substrate is given in Figure 6 . The metabolic activities of microorganisms are sensitive to $\mathrm{pH}$ changes, and the $\mathrm{pH}$ of culture media has marked effect on the type and amount of enzyme produced. Protease production by microbial strains depends on the $\mathrm{pH}$ because culture $\mathrm{pH}$ strongly influences many enzymatic processes and transport of various components across the cell membranes, which in turn support the cell growth and product production (Ellaiah et al., 2002b). The optimum $\mathrm{pH}$ for protease production was recorded at 7.0 with an activity of $98.51 \pm 2.4$ for UV 6 and $99.44 \pm 2.9 \mathrm{U} / \mathrm{ml}$ for EMS 5 respectively (Figure 6). A notable decline in protease productivity was observed at both higher and lower $\mathrm{pH}$. The optimum $\mathrm{pH}$ for the production of the protease was recorded at 7.0 when solid state fermentation of rice was carried out using A. niger (Paranthaman et al., 2009). Optimum medium $\mathrm{pH}$ of $7-8$ has been reported for maximum protease production by various species of Bacillus (Wang et al., 2008; Mahajan et al., 2012; Mahmoud et al., 2011). Radha et al., (2012) studied the production and optimization of acid protease by Aspergillus sp. from the soil. They reported a gradual increase in protease at $\mathrm{pH}$ from 3.0 to 5.0, whereas, it declined at neutral and alkaline $\mathrm{pH}$

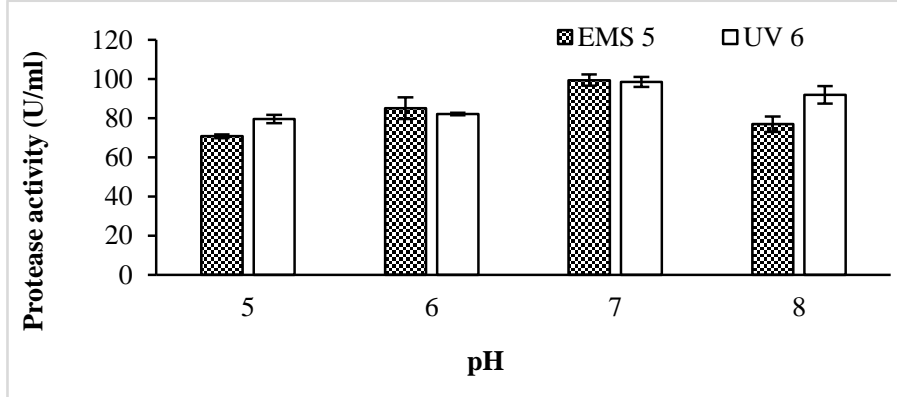

Figure 6 Effect of $\mathrm{pH}$ on protease production

\section{Effect of inoculum level}

The effect of the size of spore inoculum on the production of protease by mutan strains is illustrated in Figure 7. The size of inoculum ranged from $10^{4}$ to $10^{8}$. The result showed that maximum protease $(95.42 \pm 1.31$ and $84.61 \pm 0.58 \mathrm{U} / \mathrm{ml})$ was produced by EMS 5 and UV 6 respectively when $10^{5}$ spores $/ \mathrm{ml}$ was added to the JSC medium. An appropriate inoculum concentration is important for optimum growth and enzyme production by the microorganism. When the inoculum size was increased, it rapidly consumed the available substrate for growth and hence enzyme synthesis was decreased (Carlile $\boldsymbol{e t}$ al., 2001). The optimum level of inoculum of $10 \%$ was found to be favoring the production of alkaline protease from a mutant A.flavus AS2 (Rojarani et al., 2012).

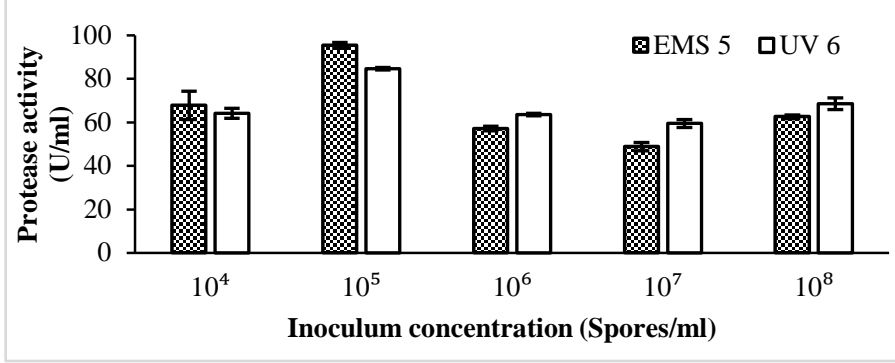

Figure 7 Effect of inoculum concentration on protease production by EMS 5 and UV 6 strains

\section{Effect of substrate concentration}

The Jatropha seed cake used in the medium for the production of protease had the proximate composition of protein- 21 , lipid- 13 , crude fibre- 8 , ash- 4.5 and carbohydrate 53\%. Optimization of JSC level was carried out by varying the amount of substrate $(1-4 \%)$ in the fermentation process. The results showed that $2 \%$ of substrate yielded maximum protease production of $99.44 \pm 2.91$ and $98.5 \pm 2.47 \mathrm{U} / \mathrm{ml}$ by EMS 5 and UV 6 strains respectively (Figure 8). It indicated that by increasing the concentration of substrate there was a decrease in protease production. Protease from a bacterial isolate B. cereus NS-2 was optimized by employing agricultural residues like wheat bran and cotton cake at $1 \%$, w/v each in the medium. Wheat bran supported fibrinolytic protease production $(148 \mathrm{U} / \mathrm{ml})$ and cotton cake enhanced fibrinolytic protease production to $315 \mathrm{U} / \mathrm{ml}$. (Bajaj $\boldsymbol{e t}$ al., 2013).

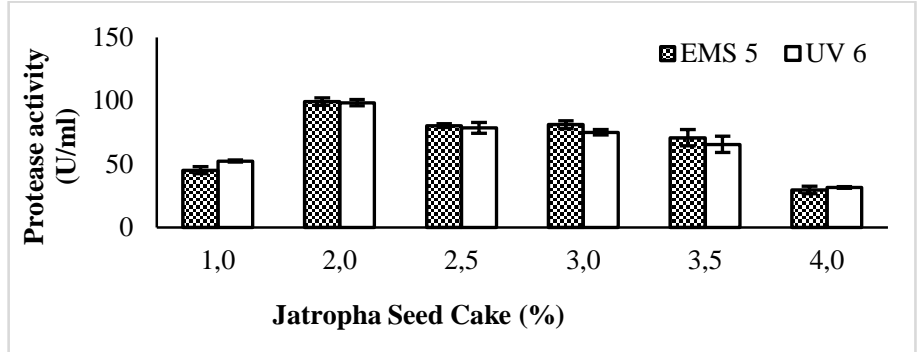

Figure 8 Effect of substrate percentage on protease production

\section{Effect of agitation}

The growth and production of the enzyme are dependent on the aeration/agitation given to the microorganism. The effect of various agitation rates of culture on protease production is shown in Figure 9. The results revealed that maximum protease was produced by EMS $5(99.44 \pm 2.91 \mathrm{U} / \mathrm{ml})$ and UV $6(98.51 \pm 2.47$ $\mathrm{U} / \mathrm{ml}$ ) at $150 \mathrm{rpm}$. Further increase in agitation rate decreased the protease production. Panta et al., (2015) have reported that $180 \mathrm{rpm}$ was optimal for higher protease activity by $B$. subtilis. The similar observation has been made for the production of alkaline protease from mutant A. flavus (Roja rani et al., 2012). They have reported that $110 \mathrm{rpm}$ as the optimum agitation rate for the production of alkaline protease by A. flavus.

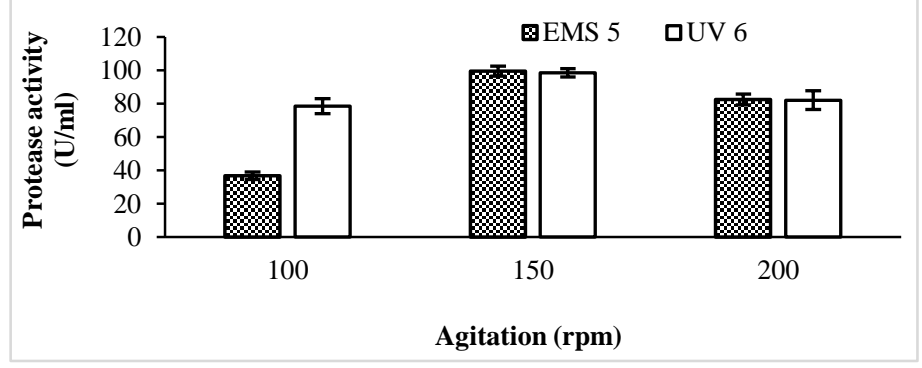

Figure 9 Effect of agitation on protease production

\section{Effect of carbon sources}

The raw material for the production of any enzyme is a significant cost determining factor. Hence, agricultural wastes are favored over synthetic media components which add to the cost of production. Production of protease is dependent on the carbon and nitrogen source available in the medium. A few carbon sources were added separately to the JSC medium to study their effect on 
enzyme production. The additional carbon sources such as glucose, maltose and soluble starch with $2 \%$ concentration were studied for the production of protease by A.terreus mutant strains EMS 5 and UV 6. The addition of maltose to JSC medium enhanced protease production, i.e., $172.32 \pm 0.29 \mathrm{U} / \mathrm{m}$ and $163.57 \pm 0.72$ U/ml by EMS 5 and UV 6 strains respectively (Figure 10). Fast metabolizable carbon sources lead to reduced enzyme production due to catabolite repression. The crude substrates are conditioned carbon sources and realize slow release of carbon and obviate catabolite repression (Bajaj \& Singh, 2010). In contrast, however, maltose enhanced protease production, in EMS-5 and UV-6 mutan strains. Raj $\boldsymbol{e t}$ al., (2012) have reported that maltose was the best carbon source among the other sugars tested with protease activity of $293 \mathrm{U} / \mathrm{ml}$. Similar results were reported where maltose enhanced protease production by three-fold from $B$. subtilis ICTF-1 (Mahajan et al., 2012). The shrimp shell powder was found to be an excellent substrate for protease production by B. cereus TKU006 (Wang et al., 2009).

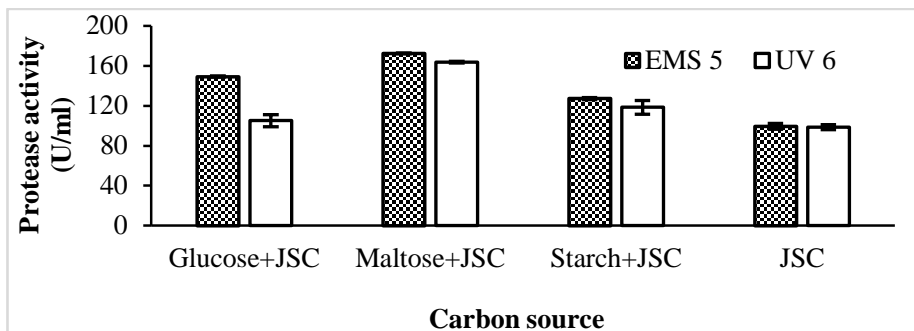

Figure 10 Effect of carbon sources on protease production (JSC=Jatropha seed cake)

\section{Effect of nitrogen source}

JSC is an excellent source of protein (21\%) and supports the protease production by the mutant strains. To study the effect of other nitrogen sources like peptone, sodium nitrate and ammonium sulphate were added to the JSC medium and the impact on the production of protease by the mutants was observed. The maximum protease production by EMS 5 and UV 6 was $99.44 \pm 2.91 \mathrm{U} / \mathrm{ml}$ and $98.51 \pm 2.47 \mathrm{U} / \mathrm{ml}$ when JSC was used in the medium. The additional nitrogen sources like peptone, sodium nitrate and ammonium sulphate did not enhance the protease production when compared to the JSC medium (without any additional source of nitrogen). Some reports indicate cotton seed cake served as a reasonably good nitrogen source for protease production from various microorganisms (Kranthi et al., 2013). Yeast extract and soy/casein peptone enhanced the fibrinolytic protease production from B. subtilis ICTF-1 (Mahajan et al., 2012). Raj et al., (2012) have tested the effect of various nitrogen sources on protease production, and it was found that yeast extract gave the highest enzyme activity of $317 \mathrm{U} / \mathrm{ml}$.

\section{CONCLUSION}

Most of the reports are on the production of protease by solid state fermentation or with soluble medium (Chutmanop et.al., 2008; Kranti et al., 2012; Ellaiah et al., 2002b). In this study, an attempt has been made to use JSC in submerged fermentation for the production of protease. The advantages of submerged fermentation over solid state fermentation are it is easy to scale-up the proces parameters. The process parameters like $\mathrm{pH}$, temperature, agitation can be controlled in submerged fermentation. The recovery and purification of the product are better with submerged fermentation. Mutagenesis followed by the subsequent selection of a strain producing superior yields is an important technique in increasing the fermentative yield of enzymes. The EMS and UV irradiation are known to affect DNA leading to thymine dimers that cause mispairing during DNA replication. This would lead to permanent mutation in the organism if there is no DNA repair. The mutation is a frequently employed technique for improving the industrial microorganisms to increase the yield of various products. There is a vast quantity of JSC generation after biodiese production in the future and disposal of JSC is a major environmental problem. Nonedible oil cakes such as Jatropha are potentially very useful for production of industrially important enzymes. The mutant strains EMS-5 and UV-6 were found to produce higher protease enzyme when compared to the parent strain A. terreus CJS-127. However, it was observed that protease production was slightly higher with EMS-5 compared to the UV-6 strain. The repeated subculturing did not affect the yield by EMS-5 and UV-6 strains and these strains were found to be genetically stable. The fermentation period was also reduced to 3 days in case of mutant strains instead of 6 days after optimization of growth conditions. The result of the present study elucidated that JSC can be an economical source for the production of protease by submerged fermentation. Because enzyme production by microorganisms is under the influence of various growth conditions, the present study determined the optimum physical and chemica parameters for maximum production of protease from the mutant strains. The use of cheap agricultural and food-processing by-products such as oil cakes, as feedstock, is highly favored to improve the commercial feasibility of bioprocess technology. The promising strains in this study could be used in various economic, industrial applications.

Acknowledgements: The authors are grateful to Ministry of Environment, Forests and Climate Change, New Delhi for the financial support. Authors thank Dr. S.G.Prapulla, Dr. H.K. Manonmani, Scientists, CFTRI, and Prof. Ram Rajasekharan, Director, CSIR-CFTRI, Mysore for their encouragement and support.

\section{REFERENCES}

Bajaj, B.K., Sharma, N., \& Singh, S. (2013) Enhanced production of fibrinolytic protease from Bacillus cereus NS-2 using cotton seed cake as nitrogen source Biocatalysis and Agricultural Biotechnology, 2, 204-209. http://dx.doi.org/10.1016/j.bcab.2013.04.003

Bajaj, B.K., \& Singh, N.P. (2010). Production of xylanase from an alkali tolerant Streptomyces sp. 7b under solid-state fermentation, its purification, and characterization. Applied Biochemistry Biotechnology, 162 (6), 1804-1818 http://dx.doi.org/10.1007/s12010-010-8960-x.

Carlile, M.J., Watkinson, S.C., \& Goody, G.W. (2001). The fungi. Ed. $2^{\text {nd }}$ London.: Academic Press, pp 475-476

Chellapandi, P., (2010). Production and preliminary characterization of alkaline protease from Aspergillus flavus and Aspergillus terreus. Journal of Chemistry, (7)2, 479-482. http://dx.doi.org/10.1155/2010/502583

Chutmanop, J,, Chuichulcherm, S., Chisti, Y., \& Srinophakun, P. (2008) Protease production by Aspergillus oryzae in solid-state fermentation using agroindustrial substrates. Journal of Chemical Technology and Biotechnology 83, 1012-1018. http://dx.doi.org/10.1002/jctb.1907

Conn, E.E., Stumpf, P.K., Bruening, G., \& Doi, R.H. (1987). Outlines of biochemistry, $5^{\text {th }}$ edition. pp. 115-164. Singapore: John Wiley and Sons, Inc.

Deng, A., WU, J., Zhang, Y., Zhang, G., \& Wen, T. (2010). Purification and characterization of a surfactant-stable high-alkaline protease from Bacillus sp B001. Bioresource Technology 101(18), 7100-7116 http://dx.doi.org/10.1016/j.biortech.2010.03.130

Ellaiah, P., Prabhakar, T., Ramakrishna, B., Taleb, A.T., \& Adinarayana, K. (2002a). Strain improvement of Aspergillus niger for the production of lipase. Indian Journal of Microbiology, 42, 151-153.

Ellaiah, P., Srinivasulu, B., \& Adinarayana, K., (2002b). A review on microbia alkaline proteases. Journal of Scientific and Industrial Research. 61, 690-704.

Endo, A., (2010). A historical perspective on the discovery of statins. Proceedings of Japanese Academy Ser. B Physical Biological Sciences. 86, 484 493. DOI: $10.2183 /$ pjab.86.484

Gupta, R., Beg, Q.K., Lorenz, P. (2002). Bacterial alkaline proteases: molecular approaches and industrial applications. Applied Microbiology and Biotechnology, 59(1) 15-32. . http://dx.doi.org/10.1007/s00253-002-0975-y Hopwood, D.A., Bibb, M.J., Chater, K.F., Kieser, T., Bruton, C.J., Kieser, H.M., Lydiate, D.J., Smith, C.P., Ward, J.M., \& Schrempt, H., (1985) Gentic manipulation of streptomyces - A Laboratory manual, Norwick:The John Innes Foundation.

Iftikhar, T.M., Niaz, S.Q., Abbas, M.A., Zia, I., Ashraf, K.J., \& Haq, I.U., (2010) Mutation induced enhanced biosynthesis of lipases by Rhizopus oligosporus., var. microsporus. Pakistan Journal of Botany, 42(4) 1235-1249.

Jellouli, K., Bougatef, A., Manni, L., Agrebi, R., Siala, R., Younes, I., \& Nasri M., (2009). Molecular and biochemical characterization of an extracellular serine-protease from Vibrio etschnikovii J1. Journal of Industrial Microbiology and Biotechnology, 36(7), 939-948. http://dx.doi.org/10.1007/s10295-009-0572-5 Kranthi, V.S., Muralidhar Rao, D., \& Jagan Mohan, P. (2012). Protease production by Rhizopus stolonifer through solid state fermentation. Central European Journal of Experimental Biology, 1(3), 113-117.

Kumar, D.J.M., Venkatachalam, P., Govindarajan, N., Balakumaran, M.D., \& Kalaichelvan, P.T., (2012). Production and purification of alkaline protease from Bacillus sp. MPTK 712 isolated from dairy sludge. Global Veterinaria, 8 (5), 433-439.

Leng, Y.W., \& Yan Xu., (2011). Improvement of acid protease production by a mixed culture of Aspergillus niger and Aspergillus oryzae using solid -state fermentation technique. African Journal of Biotechnology, 10(35), 6824-6829. http://dx.doi.org/10.5897/AJB10.2221

Lowry, O.H., Rosebrough, N.J., Farr, A.L., Randell, R.J., (1951) Protein measurement by Folin phenol reagent. Journal of Biological Chemistry, 193(1), 265-275.

Mahajan, P.M., Nayak, S., \& Lele, S.S., (2012). Fibrinolytic enzyme from newly isolated marine Bacillus subtilis ICTF-1: media optimization, purification and characterization, Journal of Bioscience and Bioengineering, 113(3), 307-314 http://dx.doi.org/10.1016/i.jbiosc.2011.10.023.

Mahmoud, M.G., Ghazy, I.A., Ibrahim, G.S., Fahmy, A.S., El-Badry, M.O. Abdel-Aty., A.M., (2011). Purification and characterization of new fibrinolytic enzyme of B. polymaxa NRC-A. International Journal of Academic Research, $3,542-547$ 
Panta, G., Prakash, A., Pavani, J.V.P., Bera, S., Deviram, G.V.N.S., Kumar, A., Panchpuri, M., \& Prasuna, R.G., (2015) Production, optimization and partial purification of protease from Bacillus subtilis. Journal of Taibah University for Science, 9, 50-55. http://dx.doi.org/10.1016/j.jtusci.2014.04.010

Paranthaman, R., Alagasundaram, K., \& Indhumathi, J., (2009). Production of Protease from rice mill wastes by Aspergillus niger in solid state fermentation. World Journal of Agricultural Sciences 5 (3), 308-312.

Radha, S, Himakiran Babu, R., Sridevi, A., Prasad, N.B.L., \& Narasimha, G., (2012) Development of Mutant fungal strains of Aspergillus niger for enhanced production of acid protease in submerged and solid state fermentation. European Journal of Experimental Biology, 2(5), 1517-1528.

Raj, A., Khess, N., Pujari, N., Bhattacharya, S., Das, A., \& Rajan, S.S., (2012). Enhancement of protease production by Pseudomonas aeruginosa isolated from dairy effluent sludge and determination of its fibrinolytic potential Asian Pacific Journal of Tropical Biomedicine, S1845-S1851.

Rathakrishnan, P., Nagarajan, P., \& Kannan, R.R., (2012). Optimization of process parameters using a statistical approach for protease production by Bacillus subtilis using cassava waste. International Journal of Chem Tech Research, 4, 749-760.

Roja rani, M., Prasad, N.N., \& Sambasivarao, K.R.S., (2012). Optimization of cultural conditions for the production of alkaline protease from a mutant Aspergillus flavus As2. Asian Journal of Experimental Biology and Science, 3,(3), 565-576.

Rowlands, R.T., (2002). Industrial strain improvement: mutagenesis and random screening procedures. Enzyme and Microbial Technology, 6(7), 3-10. http://dx.doi.org/ 10.1016/0141-0229(84)90056-5

Sharath, B.S., Mohankumar, B.V., \& Somashekar, D., (2014). Bio-detoxification of phorbol esters and other anti-nutrients of Jatropha curcas seed cake by fungal cultures using solid-state fermentation. Applied Biochemistry and Biotechnology, 117, 2747-2757. http://dx.doi.org/ 10.1007/s12010-013-0698-9

Subhan, M., Faryal, R., \& Macreadie, I., (2016) Exploitation of Aspergillus terreus for the Production of Natural Statins, Journal of Fungi, 2(13), 1-13. doi:10.3390/jof2020013 
Turk, B., (2006). Targeting proteases: successes, failures and future prospects. Nature Reviews Drug Discovery, 5(9), 785-798. http://dx.doi.org/10.1038/nrd2092

Wang, S.L., Chao, C.H., Liang, T.W., \& Chen, C.C. (2009). Purification and characterization of protease and chitinase from Bacillus cereus TKU006 and conversion of marine wastes by these enzymes. Marine Biotechnology, 11(3), 334-344, http://dx.doi.org/10.1007/s10126-008-9149-y

Yadav, S.K., Deepali, B., Shikha,\& Nandan, S.D., (2011). Oxidant and solvent stable alkaline protease from Aspergillus flavus and its characterization. African $\begin{array}{lll}\text { Journal of Biotechnology, 10(43), } & 8630-8640 .\end{array}$ http://dx.doi.org/10.5897/AJB10.1611 